\title{
Grain Yield and Its Associations With Pre-harvest Sprouting in Wheat
}

\author{
Alexsander Rigatti ${ }^{1}$, Daniela Meira ${ }^{2}$, Tiago Olivoto ${ }^{3}$, Carine Meier ${ }^{1}$, Maicon Nardino ${ }^{4}$, Andrei Lunkes ${ }^{1}$, \\ Luís A. Klein ${ }^{1}$, Fabricio Fassini ${ }^{1}$, Éderson D. Moro ${ }^{1}$, Volmir S. Marchioro ${ }^{1} \&$ Velci Q. de Souza ${ }^{5}$ \\ 1 Department of Agronomic and Environmental Sciences, Federal University of Santa Maria, Frederico \\ Westphalen Campus, Frederico Westphalen, RS, Brazil \\ ${ }^{2}$ Department of Agronomy, Federal University of Technology-Parana, Pato Branco Campus, Pato Branco, RS, \\ Brazil \\ ${ }^{3}$ Department of Fitotecnia, Federal University of Santa Maria, Santa Maria, RS, Brazil \\ ${ }^{4}$ Plant Genomics and Breeding Center, Federal University of Pelotas, Pelotas, RS, Brazil \\ ${ }^{5}$ Federal University of Pampa, Dom Pedrito, RS, Brazil \\ Correspondence: Alexsander Rigatti, Department of Agronomic and Environmental Sciences, Federal University \\ of Santa Maria, Frederico Westphalen Campus, Frederico Westphalen, Brazil. E-mail: \\ alexsanderrigatti1996@gmail.com
}

Daniela Meira, Department of Agronomy, Federal University of Technology-Parana, Pato Branco Campus, Pato Branco, RS, Brazil. E-mail: dmdanielameira94@gmail.com

Received: May 5, 2018

doi:10.5539/jas.v11n4p142
Accepted: September 3, $2018 \quad$ Online Published: March 15, 2019

URL: https://doi.org/10.5539/jas.v11n4p142

\begin{abstract}
This study aimed to evaluate direct and indirect effects of agronomic traits importance on grain yield with focus in pre-harvest sprouting. Experiment was conducted in 2017 crop season, and conducted in a randomized block design, with three replications, with eight wheat cultivars (BRS Sábia, CD 105, CD 1104, CD 1440, Frontana, Jadeíte 11, Mirante and ORS Vintecinco). Grain yield and its components were evaluated, as well as other important traits such as pre-harvest sprouting. Data were submitted to variance analysis; and phenotypic, genotypic and environmental correlations were estimated to understand grain yield expression, direct and indirect effects of its components were evaluated through path analysis. Cultivar BRS Sabiá showed shorter cycle, cultivar CD 1104 was highlighted in number of spikes per area, hectoliter weight and grain yield. And cultivars Frontana, CD 1440 and ORS Vintecinco presented the best tolerances pre-harvest sprouting. Grain yield showed high and positive phenotypic and genotypic correlations with number of ears per square meter. Furthermore, high positive direct effect of pre-harvest sprouting on grain yield, revels lower tolerance for cultivars with high grain yield. Number of spikes per square meter showed intermediate and positive direct effect and pre-harvest sprouting had the greatest direct effect on grain yield.
\end{abstract}

Keywords: Triticum aestivum L., path analysis, pre-harvest sprouting, grain yield, correlation

\section{Introduction}

Wheat (Triticum aestivum L.) is one of the main cereals produced in Brazil and in the world (USDA, 2018). Wheat grain yield and grain end-use quality, thus reduction in grain sale price is observed when pre-harvest sprouting occurs. The pre-harvest sprouting (PHS) of wheat refers to the germination of wheat grains in matured spikes before harvest due to continuous wet weather during harvest seasons (Mares \& Mrva, 2014). PHS may cause to degraded starch and protein in germinated kernels (Shorinola et al., 2016). The losses can be attend more than $\$ 1$ billion worldwide (DePauw et al., 2012).

For the germination of the seeds that occur in several complex biochemical processes controlled by genetic factors, these are influenced by environmental and at the same time water availability factors and are directly related to the seed dormancy level (Das et al., 2017). For a wheat cultivar does not present any degree of seed dormancy or any genetic or morphological mechanism that confers tolerance to PHS, occurring conditions of humidity and temperature, will occur the PHS.

The most of wheat cultivars available on the market show susceptibility to PHS. To get around this situation, solutions have been strongly sought via genetic improvement (Nörnberg, 2015; Barrero et al., 2015). 
Identification of PHS resistance genes is very important to wheat breeding (Shao et al., 2018; Jiang et al., 2018). Many of these genes are linked to hormonal signaling, abscisic acid and gibberellic acid mainly. And their synthesis is necessary to induce seed dormancy (Simlat et al., 2017).

Grain quality assurance for various purposes is highly influenced by environmental factors. One of these factors is rainfall in the harvest, which, together with the temperature and cultivar genetics, can seriously damage industrial quality of harvested grains, that is, grains in a mature spike can germinate before harvest, resulting in reduced quality (Das et al., 2017; Okuyama et al., 2017). In front of losses caused by PHS, to know correlations between grain yield, its components and other important traits, such as pre-harvest sprouting, are of great value for wheat breeding programs (Silva et al., 2005).

Based on these facts, hypotheses were formulated: (i) cultivars present variability to pre-harvest sprouting; (ii) high grain yield in wheat cultivars may reduce tolerance to pre-harvest sprouting. Thus, present work aimed to evaluate direct and indirect effects of important agronomic traits on grain yield, with focus on pre-harvest sprouting.

\section{Material and Methods}

The experiment was carried out in 2017 crop season, at Federal University of Santa Maria, Frederico Westphalen-RS campus by Genetic Breeding and Plant Production Laboratory, located at coordinates $27^{\circ} 39^{\prime} \mathrm{S}$ and $53^{\circ} 42^{\prime} \mathrm{W}, 490$ meters above sea level. According to Maluf (2000), climate is characterized as Cfa, subtropical humid, and soil is classified as dystrophic red latosol (Santos et al., 2006).

The experiment was conducted in a randomized complete block desing, with three replications eight wheat cultivars were evaluated: BRS Sabiá, CD 105, CD 1104, CD 1440, Frontana, Jadeite 11, Mirante and ORS Vintecinco. The experimental units were composed of $6 \mathrm{~m}^{2}$ plot, with row spacing of $0.17 \mathrm{~m}$ and with a plant density of 350 plants $\mathrm{m}^{-2}$. Nutritional inputs were according to soil analysis, and the phytosanitary management carried out preventively.

In the field, were evaluated days of emergence to heading (DEH), obtained by total number of days from emergence to heading; days of emergence to maturity (DEM), obtained by total number of days from emergence to maturity.

When cultivars reached physiological maturity, 10 plants per plot were harvested and phenotypic traits were measured: plant height $(\mathrm{PH})$, obtained through average of three samples in each experimental unit measured from soil to spike apex, in centimeters; number of spikes per square meter (NEM), by counting total number of spikes in two samples of 0.5 linear meters per experimental unit extrapolating to square meters; and from grain mass of plot area, grain weight (TGW), obtained through eight sub samples of 100 seeds per experimental unit, weighed on a precision balance and realized the average, in grams; hectoliter weight (HW), obtained by means of a known volume and extrapolated to $\mathrm{kg} \mathrm{h}^{-1}$; grain yield (GY), which from the total weight and correction to $13 \%$ humid, was transformed in $\mathrm{kg} \mathrm{ha}^{-1}$.

Furthermore, 20 spikes per plot were harvested to other evaluations. From these spikes, 10 were used to evaluate spike weight (SW), obtained in precision balance, in grams; spike grain weight (SGW), in precision balance, in grams. The remaining 10 spikes were used for pre-harvest sprouting test (PHS), to quantify tolerance to germination of wheat kernel in a physiological mature spike before harvest. For this, spikes were stored in laboratory for 24 hours, after they were immersed in water during eight hours, and then distributed on germitest paper sheets moistened with 2.5 times its mass with distilled water. It was conditioned in germination chamber type B.O.D for seven days, in temperature of $20^{\circ} \mathrm{C}$. After a brief visual inspection, scores were assigned from 1 (resistant) to 11 (highly susceptible) proposed by Mc Master and Derera (1976).

Analysis of variance carried out at $5 \%$ of probability of error by $\mathrm{F}$ test were performed, statistical model $Y_{i j}=\mu+g_{i}+b_{j}+\varepsilon_{i j}$, where $\mu$ is general mean of experiment, $g_{i}$ is genotype effect (cultivar) $i, b_{j}$ is block effect $j, \varepsilon_{i j}$ is random error. All effects were treated as random. Traits that revealed significance were submitted to Scott-Knott's test, considering a 5\% probability of error.

For study of genetic, phenotypic and environmental correlations between two traits ( $\mathrm{X}$ and $\mathrm{Y}$ ), they were estimated thought mean product association with treatments (PMT) and residue (PMR), obtained by:

$P M T_{x y}=\frac{Q M T_{x+y}-Q M T_{x}-Q M T_{y}}{2}$ and $P M R_{x y}=\frac{Q M R_{x+y}-Q M R_{x}-Q M R_{y}}{2}$.

Phenotypic $\left(r_{f}\right)$, genotypic $\left(r_{g}\right)$ and environmental $\left(r_{e}\right)$ correlation were estimated, respectively: 
$r_{f}=\frac{P M T_{x y}}{\sqrt{Q M T_{x} \cdot Q M T_{y}}}, r_{e}=\frac{P M R_{x y}}{\sqrt{Q M R_{x} \cdot Q M R_{y}}}$ and $r_{g}=\frac{\hat{\sigma}_{g x y}}{\sqrt{\hat{\sigma}_{g x}^{2} \cdot \hat{\sigma}_{g y}^{2}}}$, being $\hat{\sigma}_{g x y}=\frac{P M T_{x y}-P M R_{x y}}{r}$,

where, QMT is mean square of treatment, QMR is mean square of residue, $\hat{\sigma}_{g x y}$ is genotypic covariance estimator, and $\hat{\sigma}_{g x}^{2}$ and $\hat{\sigma}_{g x}^{2}$ genotypic variance estimators of $\mathrm{X}$ and $\mathrm{Y}$ traits, respectively (Cruz, 2006). To test the significance of the correlations, the $t$ test described by Steel and Torrie (1980). Genotypic correlations were submitted to bootstrap analysis with five thousand (5000) simulations to identify correlations with significance.

Aiming to identify associations among traits and how they behave, both in sense and magnitude of effects, path analysis was performed, with phonotypic correlation matrix. For that, grain yield (GY) was used as dependent trait and others as explanatory traits. In order to avoid generating disappointed data of direct and indirect effects in path analysis, it is necessary matrix is well conditioned, that is, presenting low multicollinearity. For this, multicollinearity evaluation was performed in correlation matrix through condition number $(\mathrm{CN})$, which is ratio between the highest and the lowest eigenvalue of genetic correlation matrix (Montgomery \& Peck, 1981). Traits exclusion that influenced in multicollinearity was realized by stepwise method and followed until multicollinearity reached acceptable values $(\mathrm{CN}<100)$ (Olivoto et al., 2017). All the analysis procedures were performed with statistical program Genes (Cruz, 2016).

\section{Results and Discussion}

Analysis of variance revealed significant difference among cultivars studied for traits DEH, DEM, PH, TWG, NEM, HW, PHS and GY, on the other hand SW and SGW did not present a significant difference. This fact shows that there is divergence between cultivars evaluated for different interest agronomic traits analyzed.

According to results presented in (Table 1), cultivar BRS Sabiá, launched in 2013, can be highlighted, which presented the lowest values for DEH, DEM and PH. It was observed DEH with less than 67 days and DEM at 118.7 days, noting that despite precocity, period between DEH and DEM is similar to other cultivars. According to Folini et al. (2016), cultivar presents a short cycle, which can occur at less than 60 days and maturation at 103 days. BRS Sabiá also had the lowest plant height.

Other important point is productive potential of cultivars, and in this case the highlight was CD 1104, launched in 2014, which presented the highest values for NEM and HW and consequently higher GY. In addition to high grain yield presented by cultivar, these results indicate possibility of association between these characters, fact determining since that NEM and HW are important components of GY, but it reduce tolerance to PHS.

For PHS, cultivars that presented the best tolerances were Frontana, CD 1440 and Vintecinco ORS. The cultivar Frontana was introduced in 1940, descended from the crossing between Fronteira and Mentana, when it conferred resistance to leaf rust and pre-harvest sprouting. Cultivar Frontana is one of the best sources of tolerance pre-harvest sprouting (Franco et al., 2009; Santos et al., 2010; Nörnberg et al., 2015). The Ônix/CDFAPA 2001129 and Vanguarda/Temu 2624-00, parents are responsible for good tolerance to pre-harvest sprouting presented by CD 1440 and Vintecinco ORS, respectively (De Sousa \& Caierão, 2014).

Table 1. Means for days of emergence to heading (DEH), days of emergence to maturity (DEM), plant height $(\mathrm{PH})$, thousand grain weight (TGW), number of spikes per square meter (NEM), hectoliter weight (HW), pre-harvest sprouting (PHS) and grain yield (GY)

\begin{tabular}{|c|c|c|c|c|c|c|c|c|}
\hline Cultivar & $\mathrm{DEH}$ & DEM & $\mathrm{PH}$ & TGW & NEM & HW & PHS & GY \\
\hline & \multicolumn{2}{|c|}{---------- days ---------- } & $\mathrm{cm}$ & $\mathrm{g}$ & $\mathrm{n}^{\mathrm{o}}$ & $\mathrm{kg} \mathrm{hl}^{-1}$ & note $1-11$ & $\mathrm{~kg} \mathrm{ha}^{-1}$ \\
\hline BRS Sabiá & $66.7 \mathrm{c}$ & $118.7 \mathrm{~b}$ & $62.6 \mathrm{~d}$ & $29.3 \mathrm{~b}$ & $600.5 \mathrm{~b}$ & $77.0 \mathrm{c}$ & $6.65 \mathrm{a}$ & 5034.5 \\
\hline CD 105 & $73.0 \mathrm{~b}$ & $122.7 \mathrm{a}$ & $68.8 \mathrm{c}$ & $28.9 \mathrm{~b}$ & $623.0 \mathrm{~b}$ & $77.9 \mathrm{c}$ & $5.20 \mathrm{~b}$ & $4706.9 \mathrm{t}$ \\
\hline CD 1104 & $74.3 \mathrm{a}$ & $125.0 \mathrm{a}$ & $73.7 \mathrm{~b}$ & $29.3 \mathrm{~b}$ & $713.1 \mathrm{a}$ & $83.1 \mathrm{a}$ & $5.16 \mathrm{~b}$ & 5602.7 \\
\hline CD 1440 & $73.3 \mathrm{~b}$ & $124.0 \mathrm{a}$ & $68.8 \mathrm{c}$ & $26.3 \mathrm{~b}$ & $654.6 \mathrm{~b}$ & $80.1 \mathrm{~b}$ & $2.57 \mathrm{c}$ & 3928.5 \\
\hline Frontana & $72.3 \mathrm{~b}$ & $125.0 \mathrm{a}$ & $92.1 \mathrm{a}$ & $33.3 \mathrm{a}$ & $468.4 \mathrm{~d}$ & $78.9 \mathrm{c}$ & $2.62 \mathrm{c}$ & 3643.7 \\
\hline Jadeíte 11 & $76.0 \mathrm{a}$ & $125.3 \mathrm{a}$ & $67.1 \mathrm{c}$ & $28.1 \mathrm{~b}$ & $562.5 \mathrm{c}$ & $81.4 \mathrm{~b}$ & $5.10 \mathrm{~b}$ & 3995.5 \\
\hline Mirante & $75.0 \mathrm{a}$ & $125.0 \mathrm{a}$ & $75.6 \mathrm{~b}$ & $29.5 \mathrm{~b}$ & $615.4 \mathrm{~b}$ & $78.8 \mathrm{c}$ & $6.90 \mathrm{a}$ & $4896.9 \mathrm{l}$ \\
\hline ORS Vintecinco & $73.7 \mathrm{~b}$ & $125.2 \mathrm{a}$ & $76.2 \mathrm{~b}$ & $28.4 \mathrm{~b}$ & $529.2 \mathrm{c}$ & $80.5 \mathrm{~b}$ & $2.08 \mathrm{c}$ & 4066.9 \\
\hline CV $(\%)$ & 1.113 & 0.847 & 3.015 & 3.980 & 6.019 & 1.189 & 10.819 & 6.638 \\
\hline
\end{tabular}

Note. Means followed by the same letter in column belong to the same group by the Scott \& Knott test, at $5 \%$ of probability of error. 
To better understand traits expression, genotypic $\left(r_{g}\right)$, phenotypic $\left(r_{f}\right)$ and environmental $\left(r_{e}\right)$, correlations were studied to identify associations and their magnitudes. It was observed that $84 \%$ of combinations had a genotype correlation coefficient higher than phenotypic correlation coefficients (Table 2). Data similar to those found by Kavalco et al. (2014) in wheat, by Oliveira et al. (2011) in papaya, by Correa et al. (2012) in cowpea and by Silva et al. (2008) in potatoes. These results favor selection strategy for breeding programs, since genetic effects overlap environment effects on phenotype expression.

Analyzing the genotypic, phenotypic and environmental correlations (Table 2), was verified some important correlations. We highlight strong genotypic and phenotypic correlation between DEH and DEM (0.948 and 0.921), respectively, and a mean environment correlation of 0.461 . Results that confers to those found in genotypic correlations by Vieira et al. (2007), this strong association between traits occurs due to both understanding characteristics regarding cultivars cycle, that is, tendency that when one increases the other also increases.

Traits related to crop cycle (DEH and DEM) showed strong and positive genotypic correlations with HW (0.695 and 0.740 ), respectively. The results show that longer cycle cultivars tend to have higher HW values. DEM still showed a positive and average genetic correlation with $\mathrm{PH}(0.587)$, without great influence of the environment $(-0.064)$.

PH revealed high and positive phenotypic correlation with TGW (0.819), indicating that plants with higher stature tend to present higher thousand grain weight. This association between traits is in agreement with means can be seen in (Table 1), where cultivar Frontana obtained the highest PH and TGW among eight cultivars studied. These results disagree with those found by Silva et al. (2006) with other wheat cultivars, which did not reveal significance for phenotypic correlation coefficient between PH and TGW.

SW presented strong and positive genotypic and phenotypic correlation with SGW (0.941 and 0.951), respectively, but a high influence of the environment on this association was observed (0.969). According to Falconer (1987), when environment correlation coefficients are positive they indicate traits were influenced in the same way (benefited or impaired) by the environmental variations. 
Table 2. Estimates of phonotypic $\left(r_{f}\right)$, genotypic $\left(r_{g}\right)$ and environmental $\left(r_{e}\right)$ between days of emergence to heading (DEH), days of emergence to maturity (DEM), plant height (PH), spike weight (SW), spike grain weight (SGW), thousand grain weight (TGW), number of spikes per square meter (NEM), hectoliter weight (HW), pre-harvest sprouting (PHS) and grain yield (GY)

\begin{tabular}{|c|c|c|c|c|c|c|c|c|c|c|}
\hline Variable & & DEM & $\mathrm{PH}$ & SW & SGW & TGW & NEM & HW & PHS & GY \\
\hline \multirow[t]{3}{*}{ DEH } & $r_{f}$ & $0.921^{* *}$ & 0.238 & -0.365 & -0.144 & -0.167 & 0.084 & 0.670 & -0.157 & -0.190 \\
\hline & $r_{g}$ & $0.948^{+}$ & 0.252 & -0.475 & -0.163 & -0.177 & 0.106 & $0.695^{+}$ & -0.162 & -0.194 \\
\hline & $r_{e}$ & 0.461 & -0.351 & -0.313 & -0.344 & 0.042 & -0.360 & 0.240 & 0.060 & -0.104 \\
\hline \multirow[t]{3}{*}{ DEM } & $r_{f}$ & - & 0.557 & -0.253 & -0.117 & 0.108 & -0.136 & 0.695 & -0.393 & -0.337 \\
\hline & $r_{g}$ & - & $0.587^{+}$ & -0.367 & -0.147 & 0.121 & -0.143 & $0.740^{+}$ & -0.413 & -0.365 \\
\hline & $r_{e}$ & - & -0.064 & -0.030 & -0.139 & -0.079 & -0.041 & 0.014 & 0.015 & 0.047 \\
\hline \multirow[t]{3}{*}{$\mathrm{PH}$} & $r_{f}$ & & - & 0.262 & 0.161 & $0.819^{*}$ & -0.575 & 0.097 & -0.466 & -0.400 \\
\hline & $r_{g}$ & & - & 0.308 & 0.170 & 0.850 & -0.620 & 0.086 & -0.478 & -0.431 \\
\hline & $r_{e}$ & & - & 0.476 & 0.509 & 0.173 & 0.383 & 0.385 & 0.089 & 0.327 \\
\hline \multirow[t]{3}{*}{ SW } & $r_{f}$ & & & - & $0.951^{* 4}$ & 0.389 & -0.107 & -0.266 & 0.093 & 0.429 \\
\hline & $r_{g}$ & & & - & $0.941^{+}$ & 0.493 & -0.293 & -0.516 & 0.138 & 0.527 \\
\hline & $r_{e}$ & & & - & $0.969^{* *}$ & 0.309 & 0.456 & 0.402 & -0.020 & 0.403 \\
\hline \multirow[t]{3}{*}{ SGW } & $r_{f}$ & & & & - & 0.196 & 0.079 & -0.147 & 0.173 & 0.530 \\
\hline & $r_{g}$ & & & & - & 0.223 & 0.013 & -0.368 & 0.284 & 0.750 \\
\hline & $r_{e}$ & & & & - & 0.309 & 0.333 & 0.330 & -0.011 & 0.407 \\
\hline \multirow[t]{3}{*}{ TGW } & $r_{f}$ & & & & & - & -0.684 & -0.223 & -0.104 & -0.196 \\
\hline & $r_{g}$ & & & & & - & -0.615 & -0.273 & -0.110 & -0.250 \\
\hline & $r_{e}$ & & & & & - & 0.300 & 0.346 & 0.025 & 0.567 \\
\hline \multirow[t]{3}{*}{ NEM } & $r_{f}$ & & & & & & - & 0.312 & 0.419 & $0.743^{*}$ \\
\hline & $r_{g}$ & & & & & & - & 0.292 & 0.444 & $0.767^{+}$ \\
\hline & $r_{e}$ & & & & & & - & 0.551 & -0.084 & 0.432 \\
\hline \multirow[t]{3}{*}{ HW } & $r_{f}$ & & & & & & & - & -0.278 & 0.083 \\
\hline & $r_{g}$ & & & & & & & - & -0.280 & 0.076 \\
\hline & $r_{e}$ & & & & & & & - & -0.300 & 0.169 \\
\hline \multirow[t]{3}{*}{ PHS } & $r_{f}$ & & & & & & & & - & $0.716^{*}$ \\
\hline & $r_{g}$ & & & & & & & & - & $0.752^{+}$ \\
\hline & $r_{e}$ & & & & & & & & - & -0.106 \\
\hline
\end{tabular}

Note. Genotypic correlation index ${ }^{+}$and ${ }^{++}$significant to $5 \%$ and $1 \%$ by $t$ test, respectively.

Phenotypic and environmental correlation index, * and ** significant to $5 \%$ and $1 \%$ by $t$ test, respectively.

GY revealed high and positive genotypic and phenotypic correlations with NEM (0.767 and 0.743$)$, but there was environment interference on association, although not significantly (0.432). These results are in agreement with those found in studies of genotypic and phenotypic correlations between number of fertile tillers per plant and grain yield, performed by Hartwig et al. (2007) in wheat cultivars and segregating wheat populations by Yao et al. (2014). Thus, the indirect selection of high GY cultivars through NEM is a possibility for wheat breeding programs, considering that NEM showed significant correlations with GY and had not revealed associations with other traits studied.

PHS presented high and positive genotypic and phenotypic correlations with GY (0.752 and 0.716), respectively. This indicates cultivars tendency to be more susceptible to pre-harvest sprouting when productive potential is higher, differently than would be expected. For Mares and Mrva (2014), seed dormancy is main genetic mechanism involved in control of pre-harvest sprouting. However, wheat breeding programs were designed to search for seeds with a lower level of dormancy and higher GY, aiming at faster and uniform germination in the field and consequently high productivity.

Consequently, most of wheat cultivars available on market don't express good tolerance to PHS when exposed to high humidity periods. In the incessant search for more productive cultivars, PHS was neglected, as we can observe in Table 3, cultivar more susceptible to PHS present good results for GY. Seeds with intermediate 
dormancy level are the most desirable because they do not compromise plant establishment in the field and provide a good level of tolerance to PHS (Gao \& Ayele, 2014; Shorinola et al., 2016).

Analyzing Table 3, we can observe that determination coefficient of the path analysis was 0.79 , considered of high magnitude, indicating that independent traits used in the model elucidated well direct and indirect effects for dependent trait GY.

Table 3. Estimates of direct and indirect phenotypic effects to days of emergence to heading (DEH), plant height $(\mathrm{PH})$, spike grain weight (SGW), number of spikes per square meter (NEM), hectoliter weight (HW), pre-harvest sprouting (PHS) and grain yield (GY)

\begin{tabular}{lllllll}
\hline \multirow{2}{*}{ Effect } & \multicolumn{7}{c}{ Explanatory trait } \\
\cline { 2 - 7 } & DEH & PH & SGW & NEM & HW & PHS \\
\hline Direct on GY & -0.205 & 0.120 & 0.261 & 0.463 & 0.173 & 0.511 \\
Indireto via DEH & - & 0.024 & -0.052 & 0.023 & 0.107 & -0.077 \\
Indirect via PH & -0.041 & - & 0.024 & -0.232 & 0.014 & -0.225 \\
Indirect via SGW & 0.041 & 0.011 & - & 0.102 & 0.014 & 0.051 \\
Indirect via NEM & -0.010 & -0.060 & 0.057 & - & 0.060 & 0.189 \\
Indirect via HW & -0.127 & 0.010 & 0.021 & 0.162 & - & -0.138 \\
Indirect via PHS & 0.031 & -0.053 & 0.026 & 0.171 & -0.047 & - \\
\hline Total correlation (r) & -0.180 & -0.340 & 0.480 & $0.700^{*}$ & 0.100 & $0.640^{*}$ \\
\hdashline Determination coefficient & & & & & & 0.790 \\
Variable residual effects & & & & & & 0.210 \\
Condition number & & & & & & 9.38 \\
\hline
\end{tabular}

Note. Total correlation index, ${ }^{*}$ and ${ }^{* *}$ significant to $5 \%$ and $1 \%$ by $t$ test, respectively.

DEH presented direct low and negative effect with GY (-0.205), the sum of direct and indirect effects showed low and negative total correlation (-0.180). Wheat cultivars with longer period from emergence to headgin tend to be less productive, mainly due to their exposure to adverse biotic and abiotic conditions. Thus, breeding programs target high productivity cultivars allied to short cycle. Vieira et al. (2007) observed adverse results with different wheat cultivars, with a low direct effect of DEH on GY, but total effect (sum of direct and indirect effects), high and positive.

PH generated a low and positive direct effect on RDG (0.120), but in total correlation an intermediate and negative influence was observed (-0.340), indicating absence of cause and effect. This can be attributed to the sum of direct and indirect effects, mainly of NEM and GER, which revealed low and negative indirect effects $(-0.060$ and -0.053$)$, respectively. Thus, with performance of indirect effects on $\mathrm{PH}$, smaller plants tend to present higher GY, in addition to plants of high stature are more prone to lodging. Studies and identification of associated genes with low plant height was a major advance, which allowed semi-dwarf plants selection (Henriques, 2009). According to Rodrigues et al. (2007), after release of wheat cultivars with the Rht (Reduced height) gene in the 70's, there was a great increase in grain yield, observed in the South of Brazil, due to the smaller stature of the cultivated plants.

Total correlation of SGW on GY was intermediate and positive (0.480), influenced mainly by direct low and positive explanatory trait $(0.261)$. It is evidenced that with the increase of spike grain weight, it tends to occur increase in grain yield of wheat. Kavalco et al. (2014), obtained results similar to present work. Carvalho et al. (2017) reveled direct effect of main stem spike grain mass on grain yield. However, Okuyama et al. (2004) reported positive direct effect of high magnitude for genetic correlation, but with low and negative total correlation. This is due to association between genetic and environment factors, hindering direct selection by genetic breeding programs (Vesohoski et al., 2011).

NEM reveled intermediary and positive direct effect on GY (0.463), and low and positive indirect effects via SGW (0.102), PHS (0.171) and HW (0.162), but a low and negative indirect effect of PH (-0.232). Thus, direct and indirect effects of NEM on GY revealed a high and positive total correlation (0.700). Results that confer with the high genotypic and phenotypic correlations mentioned above (Table 2), that is, increase in NEM tends to increase GY, allowing indirect selection for GY via NEM. Okuyama et al. (2004), Silva et al. (2006) and Vesohoski et al. (2011) reported similar results, where direct effects of number of spikes per square meter were 
high and positive on grain yield, but total correlation was lower, which does not indicate a lack of association between traits.

Total correlation between HW and GY was low and positive (0.100), influenced mainly by direct low and positive effects (0.173) and low and positive indirect effects of DEH (0.107). In similar work with other wheat cultivars, Silva et al. (2006) found high and positive phenotypic correlation between hectoliter weight and grain yield $(0.741)$. Thus, cultivars with greater magnitudes of hectoliter weight tend to present higher grain yield.

PHS showed highest direct effect on GY (0.511), indicating that cultivars with less tolerance PHS have highest GY in wheat. Total correlation between traits was high and positive $(0.640)$, observing low and negative indirect effects of PH (-0.225) and HW (-0.138), showing that in smaller stature plant and lower weight hectoliter, phenomenon of PHS tends to cause reduced problems. On the other hand, indirect effect of NEM was low and positive (0.189), inferring that increase in NEM leads to an increase in GY, as already mentioned, however, tendency is to increase the susceptibility pre-harvest sprouting. These results are similar to study by Felicio et al. (2002), with different wheat cultivars, where no cultivar obtained high grain yield associated with good tolerance to pre-harvest sprouting.

\section{Conclusions}

Cultivar CD 1104 was highlighted in number of spikes per area, hectoliter weight and grain yield and cultivars Frontana, CD 1440 and ORS Vintecinco presented best tolerances to pre-harvest sprouting. Indicating that the ORS Vintecinco can be used in wheat breeding programs aiming at pre-harvest sprouting tolerance.

Grain yield showed high and positive phenotypic and genotypic correlations with number of spikes per square meter. Furthermore, high positive direct effect of pre-harvest sprouting on grain yield, revels lower tolerance for cultivars with high grain yield. It's essencial breeders have more attention in selection of productive and tolerant to pre-harvest sprouting cultivars.

Number of spikes per square meter showed intermediate and positive direct effect and pre-harvest sprouting had the greatest direct effect on grain yield. Thus, number of spikes per square meter can be used to increase grain yield.

\section{References}

Barrero, J. M., Cavanagh, C., Verbyla, K. L., Tibbits, J. F. G., Verbyla, A. P., Huang, B. E., ... Gubler, F. (2015). Transcriptomic analysis of wheat near-isogenic lines identifes PM19-A1 and A2 as candidates for a major dormancy QTL. Genome Biology, 16, 93. https://doi. org/10.1186/s13059-015-0665-6

Carvalho, I. R., Nardino, M., Follmann, D. N., Demari, G. H., Olivoto, T., Pelegrin, A. J., ... Souza, V. Q. (2017). Path analysis of grain yield associated characters in Brazilians wheat genotypes (Triticum aestivum L.). Australian Jounal of Crop Science, 11, 1406-1410. https://doi.org/10.21475/ajcs.17.11.11.pne484

Correa, A. M., Ceccon, G., Correa, C. M. A., \& Delben, D. S. (2012). Estimativas de parâmetros genéticos e correlações entre caracteres fenológicos e morfoagronômicos em feijão-caupi. Revista Ceres, 59, 88-94. https://doi.org/10.1590/S0034-737X2012000100013

Cruz, C. D. (2006). Programa Genes-Estatística Experimental e Matrizes (p. 285). Viçosa: UFV.

Cruz, C. D. (2016). Genes Software - extended and integrated with the R, Matlab and Selegen. Acta Scientiarum, 38, 547-552. https://doi.org/10.4025/actasciagron.v38i3.32629

Das, A., Kim, D. W., Khadka, P., Rakwal, R., \& Rohila, J. S. (2017). Unraveling key metabolomic alterations in wheat embryos derived from freshly harvested and water-imbibed seeds of two wheat cultivars with contrasting dormancy status. Frontiers in Plant Science, 8, 1203. https://doi.org/10.3389/fpls.2017.01203

De Sousa, C. N. A., \& Caierão, E. (2014). Cultivares de trigo indicadas para cultivo no Brasil e Instituições criadoras 1922 a 2014. Embrapa Trigo-Livro científico (ALICE).

DePauw, R. M., Knox, R. E., Singh, A. K., Fox, S. L., Humphreys, D. G., \& Hucl, P. (2012). Developing standardized methods for breeding preharvest sprouting resistant wheat, challenges and successes in Canadian wheat. Euphytica, 188(1), 7-14. https://doi.org/10.1007/s10681-011-0611-y

Falconer, D. S. (1987). Introdução à genética quantitative (p. 279). Viçosa: UFV.

Franco, F. D. A., Pinto, R. J. B., Scapim, C. A., Schuster, I., Predebon, C. T., \& Marchioro, V. S. (2009). Tolerância à germinação na espiga em cultivares de trigo colhido na maturação fisiológica. Ciência Rural, 39, 2396-2401. https://doi.org/10.1590/S0103-84782009005000212 
Felicio, J. C., Camargo, C. E. O., Germani, R., \& de Freitas, J. G. (2002). Rendimento e processo germinativo do grão na espiga de genótipos de trigo. Pesquisa Agropecuária Brasileira, 37, 289-294. https://doi.org/ 10.1590/S0100-204X2002000300009

Folini, J. S. S., Bassoi, M. C., \& Silva, S. R. (2016). Indicações fitotécnicas para cultivares de trigo da Embrapa no Paraná. Embrapa, Londrina-PR.

Gao, F., \& Ayele, B. T. (2014). Functional genomics of seed dormancy in wheat: Advances and prospects. Frontiers in Plant Science, 5, 458. https://doi.org/10.3389/fpls.2014.00458

Hartwig, I., de Carvalho, F. I. F., de Oliveira, A. C., Vieira, E. A., da Silva, J. A. G., Bertan, I., ... Busato, C. C. (2007). Estimativa de coeficientes de correlação e trilha em gerações segregantes de trigo hexaplóide. Bragantia, 66, 203-218. https://doi.org/10.1590/S0006-87052007000200004

Henriques, F. S. (2009). A revolução verde e a biologia molecular. Revista de Ciências Agrárias, 32, 245-254.

Jiang, H., Zhao, L. X., Chen, X. J., Cao, J. J., Wu, Z. Y., Liu, K., ... Ma, C. X. (2018). A novel 33-bp insertion in the promoter of TaMFT-3A is associated with pre-harvest sprouting resistance in common wheat. Molecular Breeding, 38, 69. https://doi.org/10.1007/s11032-018-0830-1

Kavalco, S. A. F., Figueiredo, R., Groli, E. L., Zimmer, C. M., Baretta, D., Tessmann, E. W., ... Oliveira, A. C. (2014). Análise de trilha em genótipos de trigo submetidos ao estresse por encharcamento. Semina: Ciências Agrária, 35, 1683-1696. https://doi.org/10.5433/1679-0359.2014v35n4p1683

Maluf, J. R. T. (2000). Nova classificação climática do Estado do Rio Grande do Sul. Revista Brasileira de Agrometeorologia, 8(1), 141-150.

Mares, D. J., \& Mrva, K. (2014). Wheat grain preharvest sprouting and late maturity alpha-amylase. Planta, 240(6), 1167-1178. https://doi.org/10.1007/s00425-014-2172-5

Mc Master, G. J., \& Derera, N. F. (1976). Methodology and sample preparation when screening for sprouting damage in cereals. Cereal Research Communications, 4, 251-254.

Montgomery, D. C., \& Peck E. A. (1981). Introduction to linear regression analysis (p. 504). New York: John Wiley \& Sons.

Nörnberg, R., Silva, J. A. G. D., Luche, H. D. S., Tessmann, E. W., Kavalco, S. A. F., Zimmer, C. M., ... Oliveira, A. C. D. (2015). Tolerance to preharvest sprouting and yield of wheat genotypes from different breeding programs. Pesquisa Agropecuária Brasileira, 50, 698-706. https://doi.org/10.1590/S0100-204X201500 0800008

Okuyama, L. A., Junior, N. F., Caramori, P., \& Kohli, M. (2017). Preharvest sprouting assessment in wheat genotypes influenced by temperature and degree days. Experimental Agriculture, 54, 486-490.

Okuyama, L. A., Federizzi, L. C., \& Neto, J. F. B. (2004). Correlation and path analysis of yield and its components and plant traits in wheat. Ciência Rural, 34, 1701-1708. https://doi.org/10.1590/S0103-8478 2004000600006

Oliveira, E. J., Lima, D. S., Lucena, R. S., Motta, T. B. N., \& Dantas, J. L. L. (2011). Correlações genéticas e análise de trilha para número de frutos comerciais por planta em mamoeiro. Pesquisa Agropecuária Brasileira, 45, 855-862. https://doi.org/10.1590/S0100-204X2010000800011

Olivoto, T., Nardino, M., Carvalho, I. R., Follmann, D. N., Ferrari, M., Szareski, V. J., ... Souza, V. Q. D. (2017). REML/BLUP and sequential path analysis in estimating genotypic values and interrelationships among simple maize grain yield-related traits. Genetics and Molecular Research, 16, 1-10. https://doi.org/10.4238/ gmr16019525

Rodrigues, O., Lhamby, J. C. B., Didonet, A. D., \& Marchese, J. A. (2007). Fifty years of wheat breeding in Southern Brazil: yield improvement and associated changes. Pesquisa Agropecuária Brasileira, 42, 817-825. https://doi.org/10.1590/S0100-204X2007000600008

Santos, H. G., Jacomine, P. K. T., Anjos, L. H. C., Oliveira, V. A., Oliveira, J. B., Coelho, M. R., ... Cunha T. J. F. (2006). Sistema brasileiro de classificação de solos (2nd ed., p. 306). Rio de Janeiro: EMBRAPA.

Santos, L. T. D., Pinto, R. J. B., Franco, F. D. A., \& Schuster, I. (2010). Inheritance and potential use of grain color in the identification of genotypes resistant to pre-harvest sprouting in wheat. Crop Breeding and Applied Biotechnology, 10, 218-224. https://doi.org/10.1590/S1984-70332010000300006 
Shao, M., Bai, G., Rife, T. W., Poland, J., Lin, M., Liu, S., .. Zhang, G. (2018). QTL mapping of pre-harvest sprouting resistance in a white wheat cultivar Danby. Theoretical and Applied Genetics, 1-15. https://doi.org/10.1007/s00122-018-3107-5

Shorinola, O., Bird, N., Simmonds, J., Berry, S., Henriksson, T., Jack, P., ... Uauy, C. (2016). The wheat Phs-A1 pre-harvest sprouting resistance locus delays the rate of seed dormancy loss and maps $0.3 \mathrm{cM}$ distal to the PM19 genes in UK germplasm. Journal of Experimental Botany, 67, 4169-4178. https://doi.org/10.1093/ jxb/erw194

Silva, A. S., Cruz, P. J., Carvalho, F. I. F. D., Nedel, J. L., Silva, J. A. G. D., Caetano, V. D. R., ... Sousa, C. D. S. (2005). Análise de trilha para os componentes de rendimento de grãos em trigo. Bragantia, 64, 191-196. https://doi.org/10.1590/S0006-87052005000200004

Silva, J. A. G., Carvalho, F. I. F., Oliveira, A. C., Vieira, E. A., Benin, G., Valério, I. P.,... Ribeiro, G. (2006). Correlação de acamamento com rendimento de grãos e outros caracteres de interesse agronômico em plantas de trigo. Ciência Rural, 36, 756-764. https://doi.org/10.1590/S0103-84782006000300006

Silva, G. O., Pereira, A. D. S., Souza, V. Q. D., Carvalho, F. I. F., \& Neto, R. F. (2008). Seleção para caracteres fenotípicos de tubérculos nas primeiras gerações em batata. Revista Ceres, 55, 168-172.

Simlat, M., Nowak, M., Brutkowski, K., Hydzik, M., Zieliński, A., \& Moś, M. (2017). Expression of the aldehyde oxidase 3, ent-copalyl diphosphate synthase, and VIVIPAROUS 1 genes in wheat cultivars differing in their susceptibility to pre-harvest sprouting. Spanish Journal of Agricultural Research, 15(1), 1-9. https://doi.org/10.5424/sjar/2017151-9264

Steel, R. G. D., \& Torrie, J. H. (1980). Principles and procedures of statistics: A biometrical approach (2nd ed., p. 633). New York: McGraw-Hill.

USDA (United States Department of Agriculture, Foreign Agricultural Service). (2018). World Agricultural Production. Circular Series.

Yao, J., Yang, X., Zhou, M., \& Ma, H. (2014). Inheritance of Grain Yield and Its Correlation with Yield Components in Bread Wheat (Triticum aestivum L.). African Journal of Biotechnology, 13(12), 1379-1385. https://doi.org/10.5897/AJB12.2169

Vesohoski, F., Marchioro, V. S., Franco, F. D. A., \& Cantelle, A. (2011). Componentes do rendimento de grãos em trigo e seus efeitos diretos e indiretos na produtividade. Revista Ceres, 58, 337-341. https://doi.org/ $10.1590 / \mathrm{S} 0034-737 \mathrm{X} 2011000300014$

Vieira, E., Carvalho, F., Oliveira, A. C., Martins, L., Benin, G., Silva, J. A., ... Ribeiro, G. (2007). Análise de trilha entre os componentes primários e secundários do rendimento de grãos em trigo. Revista Brasileira de Agrociência, 13, 169-174.

\section{Copyrights}

Copyright for this article is retained by the author(s), with first publication rights granted to the journal.

This is an open-access article distributed under the terms and conditions of the Creative Commons Attribution license (http://creativecommons.org/licenses/by/4.0/). 